FIU Law Review

Volume 1

Number 1 Inaugural Issue

Article 8

Spring 2006

\title{
Returning to First Priniciples: International Human Rights as U.S. Constitutionalism
}

Natsu Taylor Saito

Georgia State University College of Law

Follow this and additional works at: https://ecollections.law.fiu.edu/lawreview

Part of the Other Law Commons

Online ISSN: 2643-7759

\section{Recommended Citation}

Natsu T. Saito, Returning to First Priniciples: International Human Rights as U.S. Constitutionalism, 1 FIU

L. Rev. 45 (2006).

DOI: https://dx.doi.org/10.25148/lawrev.1.1.8

This Symposium is brought to you for free and open access by eCollections. It has been accepted for inclusion in FIU Law Review by an authorized editor of eCollections. For more information, please contact lisdavis@fiu.edu. 


\title{
Returning to First Principles: International Human Rights as U.S. Constitutionalism
}

\author{
Natsu Taylor Saito
}

America must stand firmly for the nonnegotiable demands of human dignity: the rule of law; limits on the absolute power of the state; free speech; freedom of worship; equal justice; respect for women; religious and ethnic tolerance; and respect for private property.

These demands can be met in many ways. America's constitution has served us well. Many other nations, with different histories and cultures, facing different circumstances, have successfully incorporated these core principles into their own systems of governance. . . .

[T] he national security strategy of the United States must start from these core beliefs and look outward for possibilities to expand liberty.

The National Security Strategy of the United States ${ }^{1}$

The Constitution of the United States has long been upheld as an ideal foundation for a society concerned with preserving democracy and fundamental human rights. In those respects it has had, of course, a checkered history-initially protecting the institution of chattel slavery, ${ }^{2}$ for example, and being interpreted to allow de jure apartheid for the better part of a century after slavery was abolished and equal protection mandated. ${ }^{3}$ Nonethe-

\footnotetext{
$\dagger \quad$ Professor of Law, Georgia State University College of Law. I am grateful to Ward Churchill and Andrea Curcio for their comments and suggestions, and to all the lawyers who have been working to ensure the enforcement of international law.

1 The National Security Strategy of the United States, Policy Report prepared by the Bush Administration and released to Congress on September 19, 2002 pursuant to $\$ 108$ of the National Security Act of 1947, 50 U.S.C. 404a (1999) [hereinafter National Security Report] available at www.whitehouse.gov/nsc/nss.pdf.

2 See Paul Finkelman, Slavery and the Founders: Race And Liberty in the Age of JEFFERSON 1-33 (1996); Staughton Lynd, Slavery and the Founding Fathers, in BLACK HiSTORY: A REAPPRAISAL 115 (Melvin Drimmer ed., 1968); see generally Richard B. Lillich, The United States Constitution and International Human Rights Law, 3 HARV. HUM. RTS. J. 53 (1990) (discussing early limitations to constitutional protections).

3 See U.S. CONST. amends. XIII (1866) (abolishing slavery except as punishment upon conviction of a crime) and XIV (1868) (mandating equal protection under law); Plessy v. Ferguson, 163 U.S. 537 (1896) (holding legally mandated segregation of public accommodations to be constitutionally
} 
less, its basic provisions provide a framework which explicitly protects human rights and, by virtue of its acknowledgment of international law, allows for these protections to evolve.

Has the Supreme Court, and the judiciary more generally, consistently interpreted the Constitution in a way which furthers human rights? Clearly not. While there have been some landmark cases interpreting constitutional rights broadly and acknowledging the judiciary's responsibility to enforce international law, there have been many more in which the Court has failed to enforce internationally recognized rights, most often by deferring to the "political" branches of government.

The actions of the executive branch have a similarly checkered history. We have seen a consistent articulation of the "core principles" at issue, and frequent interventions in international fora to define basic rights, create international institutions and, on occasion, enforce these rights. Thus, the United States was a moving force in the formation of the League of Nations, the Nuremberg Tribunals and the United Nations; it played a decisive role in the drafting of the UN Charter, the Universal Declaration of Human Rights, all of the major human rights treaties promulgated since World War II, and even the Rome Treaty establishing the International Criminal Court. Yet it never joined the League of Nations; withdrew from the compulsory jurisdiction of the International Court of Justice ("ICJ"), has never become a party to most human rights treaties; insists on numerous reservations to those it does ratify; and refuses to participate in the International Criminal Court ("ICC"). ${ }^{6}$ The most frequently invoked explanation for these failures is that committing itself to such treaties or institutions would infringe on U.S. sovereignty or violate the Constitution. ${ }^{7}$

Under these circumstances can we say that United States constitutionalism is good or bad for international human rights? Is it simply a mixed bag-some good, some bad? Do the myriad instances of U.S. violation of

acceptable); Brown v. Bd. of Educ., 347 U.S. 483 (1954) (finally overturning Plessy in the context of public education). See generally A. LeON Higginbotham, JR., SHAdES OF FreEdom: Racial Politics AND PRESUMPTIONS OF THE AMERICAN LEGAL PROCESS (1996).

4 See infra notes 111-116 and accompanying text.

5 See infra notes 71-90 and accompanying text.

6 See generally Amy C. Harfeld, Oh Righteous Delinquent One: The United States' International Human Rights Double Standard - Explanation, Example, and Avenues for Change, 4 N.Y. CITY L. REV. 59 (2001); on the ICC, see generally Diane F. Orentlicher, Unilateral Multilateralism: United States Policy Toward the International Criminal Court, 36 CORNELL INT'L L.J. 415 (2004).

7 See, e.g., Kristafer Ailsliger, Why The United States Should be Wary of the International Criminal Court: Concerns Over Sovereignty and Constitutional Guarantees, 39 WASHBURN L.J. 80 (1999) (making such arguments); see also John R. Worth, Globalization and the Myth of Absolute National Sovereignty: Reconsidering the "Un-Signing" of the Rome Statute and the Legacy of Senator Bricker, 79 IND. L.J. 245 (2004) (comparing such positions to arguments made in the 1950s by those fearing that international treaties would require racial desegregation in the U.S.). 
international law ${ }^{8}$ cancel out any good that may have been done? Or has the United States, working within the constitutional framework, promoted human rights as best it could, deviating from international standards only when protecting even more important rights? One of the problems of thus framing the question is that it presumes the U.S. Constitution and legal system to be distinct and separable from international human rights law. They clearly have been interpreted as such by the Supreme Court and by officials of the U.S. government and, thus construed, have often been in conflict. But the Constitution can be-and has been-interpreted in a much different manner, one in which its relationship to international law is understood as organic and interdependent. Viewed in this light, a different question arises: is international human rights law good or bad for U.S. constitutionalism?

In this essay I sketch out some basic arguments for interpreting the Constitution as both inclusive of and dependent upon international law. From this perspective, the Constitution and the emerging international human rights regime are complementary, mutually reinforcing and integrally related systems. While this is admittedly a framing which flies in the face of much judicial opinion, the ability to envision and invoke change is, one hopes, the strength of democracy. There was, after all-to return to our initial example-plenty of judicial precedent holding slavery and racial discrimination to be constitutional before the Civil War amendments were enacted and the Supreme Court began to enforce equal protection under law, ${ }^{9}$ precedent which in many ways parallels the Supreme Court's more recent refusals to enforce human rights law. If we are willing to return to first principles, I believe we will see that international human rights law can contribute a great deal to U.S. constitutionalism.

\section{CONSTRUCTION OF A FALSE DiCHOTOMY}

We will take the actions necessary to ensure that our efforts to meet our global security commitments and protect Americans are not impaired by the potential for investigations, inquiry, or prosecutions by the International Criminal Court (ICC), whose jurisdiction does not extend to Americans and which we do not accept.

The National Security Strategy of the United States ${ }^{10}$

\footnotetext{
8 For a chronology summarizing such violations since World War II, see WARD CHURCHILL, ON THE Justice OF ROOSTING CHICKENS: Reflections ON THE CONSEQUENCES OF U.S. IMPERIAL ARROGANCE AND CRIMINALITY 97-301 (2003); on some of the most recent violations, see generally Jordan J. Paust, Executive Plans and Authorizations to Violate International Law, 43 COL. J. TRANSNAT'L L. 811 (2005).

9 See, e.g., Dred Scott v. Sanford, 60 U.S. (19 How.) 393, 407 (1856) (holding that persons of African descent were not citizens of the United States, nor even "persons" under the law).

10 National Security Report, supra note 1.
} 
Senator Claiborne Pell: "Would it not be a matter of customary law that [the Vienna Convention on the Law of Treaties] should be followed?"

Senator Jesse Helms: "Not at all. Not at all. If you do not ratify a treaty, it is like a dead cat lying on somebody's doorstep."

Congressional Record, May 18, $1988^{11}$

A. Domestic and International Law: Necessarily Distinct?

It is part of our canon that, although some states explicitly incorporate international law into domestic law at a constitutional level, the United States takes a "dualist" approach in which domestic and international law run on separate, if somewhat parallel, tracks. ${ }^{12}$

This framing, which reflects prevailing judicial doctrine, provides the foundation for the usual arguments employed to justify the United States' failure to comply with international law when it is perceived that doing so would conflict with its "national interests." Working from the presumption that international and U.S. constitutional law will at times diverge, the first argument is that, in such cases, enforcing international law would infringe on U.S. sovereignty. The second, which forms a sort of "back up" reassurance to the citizenry, is that we do not need the protections of international human rights law because the Constitution provides better protection. A corollary of this second argument is that if other states would adopt something closer to our constitutional system, their peoples would be better off, too.

This approach is reflected in the excerpt from the National Security Strategy of the United States of America ("NSS"), quoted at the beginning of this essay. Reflecting the views of the White House as reported to Congress in September 2002, the NSS first acknowledges the fundamental importance of human rights and, in a distinctly self-congratulatory manner, notes that the Constitution "has served us well" in ensuring these rights. It appears to endorse a pluralist approach, saying "[t]hese demands can be met in many ways," but if there are many ways to get there, there is only one place to go. As George W. Bush asserts in his introduction to the NSS, "The great struggles of the twentieth century between liberty and totalitarianism ended with a decisive victory for the forces of freedom - and a single

11134 Cong. Rec. S6052-01, 1988 WL 1090139 (May 18, 1988)

12 See Louis Henkin, The Constitution and United States Sovereignty: A Century of Chinese Exclusion and Its Progeny, 100 Harv. L. Rev. 853, 864-66 (1987) (discussing monism and dualism); Henry J. Steiner \& Philip Alston, International Human Rights in Context: Law, Politics, MORALS 987-1081 (2d ed. 2000) (overview of options for interpenetration of international and national systems). 
sustainable model for national success: freedom, democracy, and free enterprise."

The NSS goes on to make it clear that, in fulfilling its "responsibility to history" to "rid the world of evil," the U.S. will assert a prerogative to override international consensus should it so choose. It begins with the candid acknowledgment that "[t]he United States possesses unprecedented-and unequaled - strength and influence in the world," and goes on to explain that this power will be exercised unilaterally: "The U.S. national security strategy will be based on a distinctly American internationalism that reflects the union of our values and our national interests." ${ }^{\prime 3}$

Whether one's priority is the assurance of human rights at home or globally, the physical well-being of the American people, or adherence to Constitutional principles, this stance of American exceptionalism is problematic. First, it is a politically hypocritical position in light of the United States' stated commitment to the global rule of law, its frequent insistence that other countries adhere to internationally recognized human rights norms as well as international law more generally, and its history of influencing the articulation of human rights law and shaping the global and regional institutions which enforce it. This results in frustration and resentment around the world, and reinforces the belief that because the United States will not submit to the jurisdiction of international bodies, its influence can only be countered by means outside of such structures, one such means, of course, being terrorism. In addition to the realpolitik concerns raised by a U.S. approach which is perceived at best as paternalistic and more often as explicitly imperialist, I believe it is, in more theoretical terms, based on a false dichotomy, for compliance with international law neither infringes on U.S. sovereignty nor requires any deviation from the Constitution.

\section{B. Misconstruing Sovereignty}

The argument that state sovereignty can override international law is, I believe, exactly backwards. Returning to first principles, the United States has a claim to sovereignty because of its existence as a state which, in turn, is defined as "an entity that has a defined territory and a permanent population, under the control of its own government, and that engages in, or has the capacity to engage in, formal relations with other such entities."14

The frequently used term "nation-state" misleadingly conflates states, as defined in international law and recognized by the United States, with nations. "A nation is a cultural territory made up of communities of individuals who see themselves as 'one people' on the basis of common ances-

13 National Security Report, supra note 1 (no page numbers) (emphasis added).

14 RESTATEMENT (THIRD) OF THE ForEIGN RELATIONS LAW OF THE UNITED STATES (1987) §201. 
try, history, society, institutions, ideology, language, territory, and, often, religion." ${ }^{15}$ It is estimated that between 5,000 and 8,000 nations, so defined, exist within the territorial boundaries of the approximately 200 currently recognized states of the world. ${ }^{16}$ Nations may have historical, geographic, cultural or ethnological claims to self-determination which, while acknowledged in international law, go deeper than any legal system.

States, on the other hand, are explicitly political entities, encompassing peoples and lands acquired by force or diplomacy. As a result, their claims to legitimacy and to sovereignty over territory and peoples rest on an interstate system of mutual political acceptance; the concept of sovereignty as currently employed is rooted in the agreement of states to respect each others' territorial boundaries and internal systems of governance. ${ }^{17}$ As Alexander Aleinikoff notes, "'external' sovereignty, based as it is on a norm of noninterference, depends upon the existence and well functioning of an international regime of states with the power to recognize those entities whose sovereignty must be respected and to maintain order within the regime." ${ }^{, 18}$ States and their sovereignty are thus derivative of international law which, in turn, continues to be created by states. Because the international organizations which articulate, develop and enforce that law are comprised of states, the legal system which results explicitly protects state sovereignty and allows for measures necessary to preserve a state's "national security." In other words, sovereignty is not a trump card which can be used to override or violate international law at will; the only legitimate objections that can be raised go to whether the actions of another state or an international organization violate mutually agreed-upon rules.

15 Bernard Nietschmann, The Fourth World: Nations Versus States, in REORDERING THE WORLD: Geopolitical Perspectives on the $21^{\text {sT }}$ Century 225-26 (George J. Demko \& William B. Wood, eds., 1st ed. 1994).

16 Id. at 225. The United Nations currently lists 191 member states. See http://www.un.org/Overview/unmember.html.

17 Originally "sovereignty" referred to the relationship between the ruler and his/her subjects, usually framed in religious terms. See Louis Henkin, That "S" Word: Sovereignty, and Globalization, and Human Rights, Et Cetera, 68 FoRDHAM L. REv. 1, 1-2 (1999). In a world structured-still—within a predominantly Westphalian framework, I believe that we have the choice of moving toward an Hegelian conception of the state as all-powerful, a position articulated by Carl Schmidt, preeminent legal theorist of the Third Reich, or an understanding of the state as an explicitly political construct dependent on the mutual recognition of other states. See CARL SCHMidt, Political TheOlogy: Four Chapters ON THE CONCEPT OF SOVEREIGNTY (George Schwab trans., 1988). For a discussion of various ways in which the term is used and the inadequacies of a Westphalian model, see generally STEPHEN D. KRASNER, SOVEREIGNTY: ORGANIZED HYPOCRISY (1999).

18 T. Alexander Aleinikoff, International Law, Sovereignty, and American Constitutionalism: Reflections on the Customary International Law Debate, 98 AM. J. INT'L L. 91, 104 n.84 (2004).

19 Thus, for example, art. 4 of the International Covenant on Civil and Political Rights, 16 Dec. 1966, 999 U.N.T.S. 171, provides procedures for derogation from certain, but not all, of its provisions in "time of public emergency which threatens the life of the nation and the existence of which is officially proclaimed." 
C. Divorcing International Law from the Constitution

As a state recognized by the international community, the United States has certain fundamental rights and responsibilities under international law which are recognized by and incorporated into its Constitution. When the United States declared its independence from Britain it was at best a "rogue" state, for the European colonial powers who comprised the "civilized world" and were, therefore, the arbiters of its law, were hardly inclined to encourage colonial rebellions. ${ }^{20}$ As a practical matter, therefore, the newly formed United States desperately needed to be recognized as a legitimate state and, to this end, the founders explicitly articulated the supremacy of treaties in the Constitution, thereby assuring both the European powers and its American Indian neighbors that it was committed to the rule of law. ${ }^{21}$ It was presumed that the country was bound by, and would comply with, the underlying foundation of the "law of nations," customary international law. ${ }^{22}$

In 1793 Secretary of State Thomas Jefferson assured the French Minister that the law of nations was an "integral part" of U.S. law, and Supreme Court Chief Justice Jay affirmed that the "laws of the United States," as referenced in Articles III and VI of the Constitution, included customary international law. ${ }^{23}$ This was repeatedly articulated by governmental representatives and in judicial opinions and, thus, when Justice Gray made his oft-quoted statement in the 1900 Paquete Habana case that "[i]nternational law is part of our law, and must be ascertained and administered by the court of justice of appropriate jurisdiction, as often as questions of right depending upon it are duly presented for their determination," ${ }^{24}$ he was summarizing well over a century of U.S. jurisprudence.

That the Supreme Court has often failed to enforce international law, choosing instead to "defer" to Congress and the Executive, can thus be seen not as legitimate "constitutionalism" but the abdication of its most fundamental responsibility under Article III. If, as the founders so consistently and unequivocally stated, international law is United States law, the Constitution mandates its enforcement not only in Article VI, where treaties are

20 See Ward Churchill, The Law Stood Squarely on Its Head: U.S. Legal Doctrine, Indigenous Self-Determination and the Question of World Order, 81 ORE. L. REV. 663, 671 (2002).

21 See U.S. ConST. art. VI, cl. 2 (declaring treaties to be "the supreme Law of the Land"); Siegfried Wiessner, American Indian Treaties and Modern International Law, 7 ST. THOMAS L. REV. 567, 591 (1995). See generally Vine Deloria, Jr., Self-Determination and the Concept of Sovereignty, in ECONOMIC DEVELOPMENT IN AMERICAN INDIAN RESERVATIONS 22-28 (Roxanne Dunbar Ortiz \& Larry Emerson eds., 1979).

22 See Jordan J. Paust, International LaW As LaW of THE United States 3-66 (2d ed. 2003).

23 See id., at 7-8 (citing Jefferson, Letter as Secretary of State to French Minister Genet (June 5, 1793)); Henfield's Case, 11 F. Cas. 1099, 1101 (C.C.D. Pa. 1793); for numerous similar examples, see PAUST, INTERNATIONAL LAW, supra note 22, at 7-11.

24 The Paquete Habana, 175 U.S. 677, 700 (1900). 
specifically mentioned as part of the "supreme Law of the Land," but also in Article III's reference to "Laws of the United States." Nowhere does it say - or imply - that the balance of power so carefully created among the executive, legislative and judicial branches could or should be tipped by judicial inventions such as the "political question" or "act of state" doctrines, the "last in time" rule, the refusal to enforce treaties because they are deemed "non-self-executing,", or a blind deference to a "plenary power" of government. $^{26}$

Similarly, the argument that compliance with international law would, in certain cases, violate the constitutionally mandated balance of federal and (domestic) states' rights is without foundation. The states of the Union have certain rights vis-a-vis the federal government; ${ }^{27}$ they have no right to violate international law. Because the founders were so clear on the importance of U.S. compliance with international law, and could not afford to have the legitimacy of the country undermined by an inability to control state actions in the international realm, they specifically reserved the foreign affairs powers to the federal government. ${ }^{28}$ As Chief Justice Jay stated in 1793 in Chisholm v. Georgia, even before the Constitution was adopted, "the United States had . . . become amenable to the laws of nations; and it was their interests as well as their duty to provide, that those laws should be respected and obeyed; in their national character and capacity, the United States were responsible to foreign nations for the conduct of each state, relative to the laws of nations, and the performance of treaties . ..."29

With respect to international human rights law, not only do all of the above arguments apply, but we also have the specific protections articulated in the Bill of Rights and the blanket guarantee of Article IX, which states that " $[\mathrm{t}]$ he enumeration in the Constitution, of certain rights, shall not be construed to deny or disparage others retained by the people."30 As Jordan Paust explains, "[i]ts utility lies not in asking how internationally recognized rights can be 'implemented' into our domestic law through new legislative acts, but in recognizing that basic human rights are already a viable

25 See PaUST, InTERnational LaW, supra note 22, at 67-98 (non-self-executing treaties); 100-02 (last in time rule); 169-179 (political question and executive enforcement of treaties); 231, 305-08 (act of state doctrine).

26 For overviews of the plenary power doctrine, see generally T. ALEXANDER ALEINIKOFF, Semblances of Sovereignty: The Constitution, The State, and American Citizenship (2002); Natsu Taylor Saito, Asserting Plenary Power Over the "Other": Indians, Immigrants, Colonial Subjects, and Why U.S. Jurisprudence Needs to Incorporate International Law, 20 YALE L. \& POL. REV. 427 (2002).

27 See U.S. CONST. amend. X (1791) (powers not delegated to the federal government, nor prohibited to the states, "are reserved to the States respectively, or to the people").

28 See Henkin, Chinese Exclusion, supra note 12, at 866-67.

29 Chisholm v. Georgia, 2 U.S. (2 Dall.) 419, 474 (1793), quoted in PAUST, InTERNATIONAL LAW, supra note 22 at 8 .

30 U.S. Constitution, amend. IX (1791). 
part of the constitutionally guaranteed rights of Americans." "31 To confuse these retained rights with delegated powers, he continues, "opens the door to a false, totalitarian, and subversive concept of authority-i.e., that authority exists with the government and not with the people.",32

\section{Misrepresenting the Constitution as Conflicting with Human Rights}

Despite the explicit statements and historical context indicating that international law was to be fully incorporated into the Constitution and, thereby, into domestic law, the Constitution is often invoked as the "explanation" for why the United States does not, cannot, or need not participate in international human rights treaties or their enforcement mechanisms. ${ }^{33}$ Sometimes this comes in the form of a straightforward rejection of the international legal system as "interfering" with the prerogatives presumed to be inherent to state sovereignty, a position discussed above. A variant of this is the argument that the United States can only function within the bounds of its Constitution, is therefore only committed to human rights as explicitly articulated in the Bill of Rights, and, as a result, is limited in its enforcement of those rights to the Supreme Court's current interpretation of their reach.

The first premise of this argument could be challenged, for it is a fundamental tenet of international law that a state cannot invoke its domestic law to justify violations of international law. Not only is this specifically articulated in the Vienna Convention on Treaties, ${ }^{34}$ which, contrary to Senator Helms' assertion, has been acknowledged generally as reflecting binding customary law, ${ }^{35}$ but it was a major premise underlying the U.S.' position at the Nuremberg Tribunal. ${ }^{36}$ But it is unnecessary to engage in this debate, for there is nothing in the Constitution which precludes the enforcement of

31 Paust, International LaW, supra note 22, at 324; see also id. at 323-359.

32 Id. at 328.

33 See David Golove, Human Rights Treaties and the U.S. Constitution, 52 DePaUl L. REv. 579, 583-88 (2002) (describing "constitutional" objections to human rights treaties); Peter J. Spiro, Treaties, International Law, and Constitutional Rights, 55 STAN. L. REv. 1999, 2002-17 (2003) (discussing the doctrine of "constitutional hegemony").

34 Art. 27, Vienna Convention on the Law of Treaties, U.N. Doc. A/CONF.39/27 at 289 (1969), 1155 U.N.T.S. 331 (entered into force Jan. 27, 1980) ("A party may not invoke the provisions of its internal law as justification for its failure to perform a treaty.").

35 See Restatement (THIRD) OF THE Foreign RELATIONS LAW OF THE UNited STATES (1987) § 325 , cmt. a (noting that the Vienna Convention "represents generally accepted principles and the United States has also appeared willing to accept them despite differences of nuance and emphasis"); SIR IAN Sinclair, THE VienNa CONVENTION ON THE LAW OF TREATIES 5-10 (2d ed. 1984).

36 See Matthew Lippman, The Other Nuremberg: American Prosecutions of Nazi War Criminals in Occupied Germany, 3 IND. INT'L \& COMP. L. REV. 1, $62-75$ (1992) (on the trial of Nazi prosecutors, judges and Justice Ministry officials); see generally Henry T. King, Jr., The Legacy of Nuremberg, 34 CASE W. Res. J. InT'L L. 335 (2002); From NuREmberg to My LaI, esp. 3-136 (Jay W. Baird ed., 1972). 
international law. To the contrary, one can make a very solid argument that it mandates such enforcement. ${ }^{37}$ As the Ninth Amendment states explicitly, the protections enumerated in the first eight amendments are not the outer limits, as it were, of human rights protection, but simply a subset of guaranteed rights. Combined with the Constitution's incorporation of international law generally, the "rights retained by the people" surely include all fundamental human rights. The Supreme Court could - and, I would argue, should-interpret the Bill of Rights in a manner congruent with the broader human rights regime. But to the extent it fails to do so, there is nothing in the Constitution which precludes Congress or the Executive from recognizing broader rights.

A more sophisticated version of this argument involves the assertion that the Constitution protects rights not yet recognized by the human rights regime, which would be infringed upon by compliance with certain international norms. Thus, for example, it is argued that prohibiting "hate speech" as required by the International Convention on the Elimination of All Forms of Racial Discrimination ("ICERD") 38 would infringe on First Amendment freedom of speech. Yet First Amendment jurisprudence illustrates that speech has been restricted in many circumstances, such as the advocacy of imminent violence, and there is currently an intra-constitutional debate about the extent to which enforcement of Fourteenth Amendment equal protection requires a similar limitation of speech designed to incite racial hatred or violence. ${ }^{39}$

Such arguments must be countered on a case-by-case basis requiring a detailed analysis beyond the scope of this essay. However, there are very few cases in which such a conflict actually arises ${ }^{40}$ and, given the long history of working out a balance between rights when they come into conflict in domestic jurisprudence, there is no reason to believe a similar process cannot be fruitfully employed when the mandates of the Constitution and human rights law appear to be at odds. At most, it would require some very

37 See Thomas Buergenthal, Modern Constitutions and Human Rights Treaties, 36 CoL. J. TRANSNAT'L L. 211, 212 (1997) (“contemporary U.S. practice with regard to [human rights] treaties is neither constitutionally necessary nor compatible with the long-term interest of the United States").

38 Mar. 7, 1966 (entered into force Jan. 4, 1969), G.A. Res. 2106, 600 U.N.T.S. 195. ICERD, 600 U.N.T.S. 195. The parties agree, under Art. 4, to criminalize the dissemination of ideas based on racial superiority or hatred, ban organizations that promote and incite racial discrimination, and prohibit public authorities and institutions from promoting or inciting racial discrimination.

39 See generally Alexander Tsesis, Regulating Intimidating Speech, 41 HARV. J. ON LEGISL. 389 (2004); Richard Delgado and Jean Stefancic, Must We Defend NaZis? Hate SpeEch, Pornography, AND the NeW First AMENDMENT (1997); John A. Powell, Worlds Apart: Reconciling Freedom of Speech and Equality, 85 KY. L.J. 9 (1997); MARI J. MATSUDA, WordS That Wound: Critical RACE THEORY, Assaultive SPEECH, AND THE FIRST AMENDMENT (1993).

40 See generally Johan D. van der Vyver, American Exceptionalism: Human Rights, International Criminal Justice, and National Self-Righteousness, 50 EMORY L.J. 775 (2001) (dispelling many of the claimed conflicts with both human rights treaties and the Rome Treaty establishing the ICC). 
limited reservations to the ratification of some treaties, not a blanket refusal to go beyond existing constitutional jurisprudence. There is, to reiterate, nothing inherent to U.S. constitutionalism that needs to constrict the human rights regime. ${ }^{41}$

\section{Is THE CONSTITUtion A Viable AlteRnAtive?}

One of the great paradoxes of the progress of human rights thinking is that many prominent governments . . basically believe that human rights are only relevant for other countries. Human rights are treated as above all an instrument of foreign policy....

One of the most harmful features of Western-style global dominance is the perpetual rediscovery of its own perceived innocence ... . [The United States] retains its sense of self as the last best hope of humanity, as the "city on the hill"....

This self-righteous diplomacy is producing a new crusader mentality that underpins the advocacy of humanitarian intervention, the geographic axis of which runs always North to South, with no contemplation that perhaps there are circumstances of abuse that might validate South-to-North forms of intervention.

\section{Richard Falk, Human Rights Horizons ${ }^{42}$}

As reflected in this excerpt, there is a belief, frequently expressed by those who still consider themselves to represent the "civilized world," that human rights law addresses other people's problems. ${ }^{43}$ When this attitude manifests as American exceptionalism it is the basis for widespread accusa-

41 For a different approach with similar results, see generally Francisco Forrest Martin, Our Constitution as Federal Treaty: A New Theory of United States Constitutional Construction Based on An Originalist Understanding for Addressing a New World, 31 HASTINGS CONST. L.Q. 269 (2004) (advocating interpretation of the Constitution as a treaty).

42 Richard A. Falk, Human Rights Horizons: The Pursuit of Justice in a Globalizing WORLD 57, 87, 90 (2000)

43 See generally Makau Mutua, Savages, Victims, and Saviors: The Metaphor of Human Rights, 42 HARV. INT'L L.J. 201 (2001). When the United States has been accused of violating fundamental human rights or failing to comply with the laws of war with respect to those deemed "Other" we often hear the rationalization that, because the Other is "uncivilized," the U.S. need not comport with otherwise applicable law. See generally Richard Drinnon, FACING WeSt: The METAPHYSiCs of IndianHATING AND EMPIRE-BUILDING (1990) (illustrating this phenomenon with respect to American Indians and the war in Vietnam); Stuart Creighton Miller, "Benevolent Assimilation": The American CONQUEST OF THE PHILIPPINES, 1899-1903 (1982) (discussing the treatment of Filipinos). In the context of the current war in Iraq, see Michael J. Frank, Justice for Iraq, Justice for All, 57 OKLA. L. REv. 303, 305 n.18 (2004) (citing statements by Ann Coulter and Alan Dershowitz). 
tions of U.S. hypocrisy. ${ }^{44}$ A somewhat more subtle variation of this approach is found in the assertion that the United States need not consider international human rights law to be binding upon itself because the Constitution already guarantees the protections addressed in human rights law and, in fact, offers better protection. It is those deemed "Other" who need human rights protection and, therefore, it is a legitimate issue of foreign but not domestic policy.

One layer of this argument is, at its core, that our constitutional regime provides better, or at least sufficient, safeguards for all those under U.S. jurisdiction. When specific examples of the U.S. failure to provide such protection are raised, we often see a retreat to the position that, even if there are others whom the system has on occasion failed, we (i.e., the citizenry, or some subset thereof $f^{45}$ ) do not need to be concerned because we are protected. The subtext of this message is that citizens, those to whom the government should be most responsive, should not attempt to invoke the democratic processes of governmental or judicial accountability because, somehow, it is not our problem.

There are two basic problems with this line of reasoning. The first is the myriad of instances in which the Constitution has been interpreted to provide protections that fall short of the requirements of international human rights law, both with respect to citizens and noncitizens. The second is that the courts have failed to impose otherwise applicable constitutional limits to executive and legislative action in a number of areas, on some variant of the theory that the Executive branch, alone or in concert with Congress, has plenary-i.e., full and absolute-power to which the courts will defer. This plenary authority is exercised over both citizens and noncitizens, with the result that the class of "fully protected" citizens is much narrower than generally presumed.

\section{A. Human Rights Law as Currently Implemented}

Responding first to the argument that the U.S. Constitution provides "better" protection of basic human rights than prevailing international law, a brief comparison is in order. The United States has yet to become a party to a number of major human rights treaties, most notably the Convention on

44 See generally Julie A. Mertus, BAIT AND Switch: Human Rights AND U.S. ForeIGN POLICY (2004) (arguing that human rights rhetoric is used by the U.S. to entice compliance by other countries, then used to promote its interests); van der Vyver, supra note 40.

45 In the context of the "war on terror," see generally Natsu Taylor Saito, For "Our" Security: Who is an "American” and What is Protected by Enhanced Law Enforcement and Intelligence Powers?, 2 Seattle J. Soc. Just. 23 (2003); Thomas W. Joo, Presumed Disloyal: Executive Power, Judicial Deference, and the Construction of Race Before and After September 11, 34 COL. HUM. RTS. L. REV. 1 (2002). On the racialized construction of identity and citizenship, see generally Tayyab Mahmud, Colonialism and Modern Constructions of Race: A Preliminary Inquiry, 53 U. MIAMI L. REV. 1219 (1999); IAN F. Haney LopeZ, White By LaW: The Legal Construction of RaCE (1996). 
the Rights of the Child, ${ }^{46}$ the Convention on the Elimination of All Forms of Discrimination Against Women, ${ }^{47}$ and the International Covenant on Economic, Social and Cultural Rights. ${ }^{48}$ The treaties to which it is a party, including the Convention on the Prevention and Punishment of the Crime of Genocide, ${ }^{49}$ the International Covenant on Civil and Political Rights, ${ }^{50}$ the Convention Against Torture and Other Cruel, Inhuman or Degrading Treatment or Punishment, ${ }^{51}$ and the Convention on Racial Discrimination ${ }^{52}$ have all been ratified with an extensive package of reservations, understandings and declarations which, among other things, attempt to limit U.S. compliance to the obligations it has already acknowledged under the U.S. Constitution. ${ }^{53}$ While portrayed as an attempt to avoid conflict with the Constitution, in fact these amount to a statement that "adherence to an international human rights treaty should not effect-or promise-change in existing U.S. law or practice." ${ }^{5}$

If it were the case that the Constitution provides equivalent or better protection of the rights delineated in these treaties, such caveats would, presumably, be unnecessary. In fact, however, the Constitution has not been interpreted to provide equivalent rights. The most glaring example of this is the United States' insistence on retaining the death penalty in the face of a powerful international movement for its abolition, ${ }^{55}$ and particularly its (1989)

46 Nov. 20, 1989, G.A. Res. 25 ,U.N. GAOR, 44th Sess., Supp. No. 49, at 167, U.N. Doc. A/44/49

47 G.A. Res. 34/180, U.N. GAOR, 34th Sess., Supp. No. 46 at 194, U.N. Doc. A/34/830 (1979) (entered into force Sept. 3, 1981). Over ninety percent of UN member states were parties by 2004. See Marjorie Cohn, Resisting Equality: Why the U.S. Refuses to Ratify the Women's Convention, 27 T. JEFFERSON L. REV. 15, 16, 22-23 (2004).

48 G.A. Res. 2200, U.N. GAOR, 21st Sess., Supp. No. 16 at 49, U.N. Doc. A/6316 (1967) (entered into force Jan. 3, 1976)

49 Convention on the Prevention and Punishment of the Crime of Genocide, Dec. 9, 1948, 78 U.N.T.S. 277 (entered into force Jan. 12, 1951)

50 G.A. Res. 2200, U.N. GAOR, 21st Sess., Supp. No. 16 at 52, U.N. Doc. A/6316 (1967) (entered into force Mar. 23, 1976)

51 G.A. Res. 39/46, U.N. GAOR, 39th Sess., Supp. No. 51 at 197, U.N. Doc. E/CN.4/1984/72, (1984) (entered into force June 26, 1987).

$52 \quad$ Supra note 38.

53 See Louis Henkin, U.S. Ratification of Human Rights Conventions: The Ghost of Senator Bricker, 89 AM. J. INT'L L. 341, 341-48 (1995).

54 Id. at 341.

55 As of 2004, 117 states had abolished the death penalty in law or in practice; the majority of executions now take place in the U.S., China, Vietnam and Iran. See John Paul Truskett, The Death Penalty, International Law, and Human Rights, 11 TulsA J. COMP. \& INT'L L. 557, 558-59 (2004); see generally Stephen B. Bright, Will the Death Penalty Remain Alive in the Twenty-First Century?: International Norms, Discrimination, Arbitrariness, and the Risk of Executing the Innocent, 2001 WIS. L. REV. 1 (2001) (noting the disparity of U.S. practice from international norms, as well as resultant injustices). The U.S. has not ratified the Second Optional Protocol to the ICCPR, intended to abolish capital punishment altogether, Dec. 15, 1989, G.A. Res. 44/128, UN GAOR $44^{\text {th }}$ Sess., Supp. No. 49, at 207, 1642 U.N.T.S. 414. 
consistent reservation of the "right" to execute juveniles, ${ }^{56}$ a practice which was not abolished under domestic law until 2005. ${ }^{57}$ This, along with its practice of allowing youth under the age of eighteen to serve in the military, has been a primary reason the U.S. stands still alone-with Somalia-in refusing to become a party to the Convention on the Rights of the Child. ${ }^{5}$

The United States has also been criticized for its failure to comport with international human rights norms because of its rate of incarcerationwith only five percent of the world's population, the U.S. holds twenty-five percent of its prisoners, ${ }^{59}$ the racially disparate implementation of its criminal laws ${ }^{60}$ and conditions of incarceration which are cruel, inhuman or degrading. ${ }^{61}$ As Johan van der Vyver notes, "The internal American legal system has fallen far behind international standards of criminal justice: any legal system that leaves scope for a child to be sent to prison for life without the option of parole for a crime committed while the child was twelve years of age is in dire need of drastic reform." ${ }^{, 2}$ The International Court of Justice recently found the U.S. in violation of a treaty requiring consular notification when foreign nationals are arrested, ${ }^{63}$ and the U.S.'s treatment of those seeking political asylum is widely considered to violate refugee law. ${ }^{64}$

56 Art. 6(5) of the ICCPR specifically prohibits its imposition for crimes committed by those younger than eighteen. While the U.S. claims that its reservations allow it to continue the practice, recent opinions of the Inter-American Commission on Human Rights have stated that this is now a binding jus cogens norm. See Stéphane Bourgon and Muriel Cauvin, Judgments and Decisions Issued by International Courts and Other International Bodies on Human Rights in 2003, 3 J. INT'L CRIM. Just. 296, 301-302 (2005) (discussing the Shaka Sankofa and Douglas Christopher Thomas cases).

57 See Roper v. Simmons, 125 S. Ct. 1183 (2005) (holding that execution for a crime committed before the age of 18 violates Eighth and Fourteenth Amendment protections).

58 See generally John Quigley, U.S. Ratification of the Convention on the Rights of the Child, 22 St. Louis U. Pub. L. ReV. 401 (2003); Stuart N. Hart, Non-Governmental Efforts Supporting U.S. Ratification of the Convention on the Rights of the Child, 4 LOY. Pov. L.J. 141 (1998).

59 See Stephen C. Thaman, Is America A Systematic Violator of Human Rights in the Administration of Criminal Justice? 44 St. LOUIS U. L.J. 999, 1000 n.7 (2000).

60 See generally Nkechi Taifa, Codification or Castration? The Applicability of the International Convention to Eliminate All Forms of Racial Discrimination to the U.S. Criminal Justice System, 40 How. L.J. 641 (1997) (applying ICERD standards to U.S. practice); Terry D. Johnson, Unbridled Discretion and Color Consciousness: Violating International Human Rights in the United States Criminal Justice System, 56 RUTGERS L. REV. 231 (2003) (discussing the potential for ICERD to address racial discrimination in the criminal justice system).

61 See generally Alvin J. Bronstein \& Jenni Gainsborough, Using International Human Rights Laws and Standards for U.S. Prison Reform, 24 PACE L. Rev. 811 (2004) (comparing Eighth Amendment jurisprudence with international standards).

62 van der Vyver, supra note 40 at 832.

63 See Case Concerning Avena and Other Mexican Nationals (Mex. v. U.S.), 2004 I.C.J. 128 (Mar. 31), http://www.icj-cij.org/icjww/idecisions.htm (holding U.S. in violation of the Vienna Convention on Consular Relations); see generally Linda E. Carter, Lessons from Avena: The Inadequacy of Clemency and Judicial Proceedings for Violations of the Vienna Convention on Consular Relations, 15 DUKE J. COMP. \& INT'L L. 259 (2005).

64 See generally Jaya Ramji, Legislating Away International Law: The Refugee Provisions of the Illegal Immigration Reform and Immigrant Responsibility Act, 37 STAN. J. INT'L L. 117 (2001) (noting 
These are but a few examples of the United States' failure to comply with international norms within the realm of civil and political rights, rights the U.S. claims are both fundamental and fully protected by the Constitution. Another realm of rights recognized under international laweconomic, social and cultural rights-has effectively been banned from U.S. discourse. These are framed in fairly general terms in the Universal Declaration of Human Rights, recognized as embodying customary law; in the International Covenant on Economic, Social and Cultural Rights, which the U.S. signed in 1976 but has yet to ratify; and in a number of additional treaties such as the Convention on the Rights of the Child and the Convention on the Elimination of Discrimination Against Women, neither of which the U.S. has ratified.

Broadly speaking this realm encompasses the right to work; to equal pay and protection against systemic unemployment; to formation of trade unions; to food, clothing, housing, medical care and education; and to participation in cultural, scientific and literary life. ${ }^{65}$ In what most would view as a fundamental violation of such rights, poverty, unemployment and homelessness are significant and increasing problems in the U.S., ${ }^{66}$ and tens of millions of Americans are without access to decent health care or education. $^{67}$ There is nothing in the Constitution which would prevent federal, state or local governments from providing a guarantee of minimal income, housing, food or medical care and, in fact, a number of states recognize such rights under their constitutions. ${ }^{68}$ Nonetheless, the Supreme Court has

the Act's breach of international law pertaining to arbitrary detention, due process, non-refoulement and political asylum); David A. Martin, Strategies for a Resistant World: Human Rights Initiatives and the Need for Alternatives to Refugee Interdiction, 26 CORNELL INT'L L.J. 753 (1993) (discussing human rights problems associated with the policies of interdiction); Arthur C. Helton, The Mandate of U.S. Courts to Protect Aliens and Refugees Under International Human Rights Law, 100 YALE L.J. 2335 (1991) (examining the interdiction of Haitian refugees, detention of Cuban asylum seekers, and the judiciary's use of international law in interpreting U.S. statutes).

65 See generally Philip Alston, U.S. Ratification of the Covenant on Economic, Social and Cultural Rights: The Need for an Entirely New Strategy, 84 AM. J. INT'L L. 365 (1990); Barbara Stark, Economic Rights in the United States and International Human Rights Law: Toward an "Entirely New Strategy," 44 HASTINGS L.J. 79 (1992).

66 In 2001 there were 32.9 million people in the U.S. living in poverty, an increase of 1.3 million in one year; unemployment was officially $6 \%$ in 2003, and the 2000 census reported 2.3 million people, including children, without shelter at least once a year. Robert Doughten, Filling Everyone's Bowl: A Call to Affirm a Positive Right to Minimum Welfare Guarantees and Shelter in State Constitutions to Satisfy International Standards of Human Decency, 39 GonZ. L. REv. 421, 424-25 (2003-2004); see generally Maria Foscarinis, Homelessness and Human Rights: Towards an Integrated Strategy, 19 ST. LOUIS U. PUB. L. REV. 327 (2000).

67 See generally Eleanor D. Kinney, The International Human Right to Health: What Does This Mean for Our Nation and World?, 34 IND. L. Rev. 1457 (2001); James A. Gross, A Human Rights Perspective on U.S. Education: Only Some Children Matter, 50 CATH. U. L. REV. 919 (2001).

68 On the potential for using state constitutional protections, see generally Scott T. Jenkins, The Influence of International Human Rights Law on State Court and State Constitutions, 90 AM. Soc. INT'L L. PROC. 259 (1996) (panel discussion); Ann I. Park, Human Rights and Basic Needs: Using Interna- 
not recognized any of these as rights as enforceable under the Constitution. $^{69}$

B. Law "Outside" the Constitution?

\section{The Plenary Power Doctrine}

In the examples referenced above, the Constitution is acknowledged to apply, but has been interpreted in a manner more restrictive than applicable international human rights norms. Thus, even where the Court has found no right to welfare or housing, it has engaged in a process of constitutional scrutiny, applying its "normal" (Fifth or Fourteenth Amendment) analysis. A larger problem from the perspective of human rights jurisprudence is that there are a number of areas in which the Supreme Court has simply refused to engage in such constitutional analysis, going back at least as far as the "plenary power" cases of the late 1800s.

The U.S. government has consistently refused to extend otherwise applicable constitutional protections to American Indian nations and "unincorporated territories"-i.e., external colonies—such as Puerto Rico. Despite the newly established republic's explicit recognition of the sovereignty of American Indian nations, including its reliance upon treaties with them, by the 1830s the Supreme Court had unilaterally declared them "domestic dependent nations" whose relationship to the United States was that of a "ward" to a "guardian.", This was more formally articulated in the 1903 case of Lone Wolf $v$. Hitchcock, when the Supreme Court made the clearly counter factual statement that "[p]lenary authority over the tribal relations of the Indians has been exercised by Congress from the beginning, and the power has always been deemed a political one, not subject to be controlled by the judicial department of the government." ${ }^{72}$ On that basis the Court upheld the 1887 Allotment Act despite its incompatibility with both the due

tional Human Rights Norms to Inform Constitutional Interpretation, 34 UCLA L. REV. 1195 (1987); Stark, supra note 65; Doughten, supra note 66.

69 See, e.g., Dandridge v. Williams, 397 U.S. 471, 485-86 (1970) (no constitutional right to welfare); Lindsey v. Normet, 405 U.S. 56, 74 (1972) (no fundamental right to housing); San Antonio Indep. Sch. Dist. v. Rodriguez, 411 U.S. 1, 35 (1973) (no constitutional right to education; disparate financing of public education does not trigger strict scrutiny); Maher v. Roe, 432 U.S. 464, 469 (1977) (states have no constitutional responsibility for medical expenses of indigents).

70 See Wiessner supra note 21 at 591 (noting that the U.S. initially "enter[ed] into treaties of friendship and alliance on a perfectly level playing field with . . . Indian nations . . . extending to them the same courtesies as to other nations of the then overwhelmingly European international legal order").

71 Cherokee Nation v. Georgia, 30 U.S. (5 Pet.) 1, 17 (1831); see generally Helen W. Winston, “An Anomaly Unknown”: Supreme Court Application of International Law Norms on Indigenous Rights in the Cherokee Cases (1831-32), 1 TulSA J. COMP. \& INT'L L. 339 (1994).

72 Lone Wolf v. Hitchcock, 187 U.S. 553, 565 (1903); see generally BLUE CLARK, LONE WOLF V. HitCHCOCK: TREATY RightS \& INDIAN LAW AT THE END OF THE NINETEENTH CENTURY (1994). 
process clause of the Fifth Amendment and the explicit terms of an 1867 treaty. ${ }^{73}$

This judicial doctrine of plenary power has consistently been invoked to allow Congress and the Executive to engage in otherwise unconstitutional actions against American Indian nations with no semblance of judicial restraint, ${ }^{74}$ resulting, for example, in generations of American Indian children being forced into abusive "boarding schools,", and the government's current inability to account for more than one hundred billion dollars it confiscated and held "in trust" for individual American Indians.

Similarly, the United States has, since 1898, exercised jurisdiction over "unincorporated territories" without extending the protections of the Constitution to their inhabitants. From 1898 to 1946 the U.S. considered Filipinos "wards" of the United States, "nationals" who owed allegiance to the U.S. but were not entitled to the full benefits of citizenship. ${ }^{77}$ In 1901 Justice White declared in Downes v. Bidwell that Puerto Rico "was foreign to the United States in a domestic sense," 78 a description that still holds as, after a century of U.S. rule, Puerto Ricans have no representation in Congress, only qualified citizenship and no right to determine their own political status. To quote Burke Marshall and Christina Duffy Burnett, "[T]he unincorporated territories were [and still are] denied even the promise of any final status, either within the constitutional framework or outside of it. They were [and are] subjected not only to an unequal condition but also to absolute uncertainty ....,"79

With respect to the exercise of U.S. jurisdiction over both American Indian nations and external territories, the Supreme Court has thus simply announced that it will not hold Congress or the Executive to even minimal

\footnotetext{
73 Saito, Asserting Plenary Power, supra note 26, at 441.

74 See generally Nell Jessup Newton, Federal Power over Indians: Its Sources, Scope, and Limitations, 132 U. PA. L. REV. 195 (1984).

75 See generally Ward ChURChill, Kill the Indian, SAVE the Man: The GenOcidal IMPACT OF AMERICAN INDIAN RESIDENTIAL SCHOOLS (2004).

76 See Cobell v. Norton, 334 F.3d 1128 (D.C. Cir. 2003) (rulings in class action suit filed in 1996 for unaccounted-for American Indian trust monies); see also Jennifer Talhelm, Inside Washington: Cowboy judge in Indian case holds little back, AP Alert, Nov. 28, 2005 (noting the lawsuit claims the Interior Department mishandled more than $\$ 100$ billion in royalties); Diana Marrero, Tribal members place renewed urgency on resolving landmark lawsuit, Muskogee DAILY PHOENIX \& Times DEMOCRAT, Nov. 18, 2005, at 1 (noting charges of governmental "squandering" of $\$ 137$ billion).

77 See Avelino J. Halagao, Jr., Citizens Denied: A Critical Examination of the Rabang Decision Rejecting United States Citizenship Claims by Persons Born in the Philippines During the Territorial Period, 5 AsIAN PAC. AM. L.J. 77, 77-78 (1998).

78 Downes v. Bidwell, 182 U.S. 244, 341-42 (1901) (White, J., concurring).

79 Christina Duffy Burnett \& Burke Marshall, Between the Foreign and the Domestic: The Doctrine of Territorial Incorporation, Invented and Reinvented, in FoREIGN IN A DOMESTIC SENSE: PUERTO RiCO, AMERICAN EXPANSION, AND THE CONSTITUTION 1, 12 (Christina Duffy Burnett \& Burke Marshall eds., 2001); see generally EFRÉn RIVERA RAMOS, THE LEgAL CONSTRUCTION OF IDENTITY: THE Judicial AND SOCIAL LEGACY OF AMERICAN COLONIALISM In PUERTO RiCo (2001).
} 
constitutional constraints. Under these circumstances, for the United States to invoke its constitutionalism as an excuse not to comport with international law is not only illogical, but amounts to the abandonment of any pretense that the rule of law matters.

Beginning with the Chinese exclusion cases of the 1880s, the plenary power doctrine has been invoked by the Supreme Court in immigration matters. In 1889 Chae Chan Ping, a permanent resident, challenged a statute which was passed during his absence and prevented his reentry. The Supreme Court acknowledged that the law conflicted with the Burlingame Treaty but refused to enforce the treaty, invoking the "last in time" rule, and denied Chae Chan Ping's Fifth Amendment due process claim with the assertion that, because of its plenary authority, Congress' "determination is conclusive upon the judiciary." ${ }^{, 81}$ Shortly thereafter, in another Chinese exclusion case, the Court extended Congress' plenary power from exclusion to deportation, refusing to characterize deportation as punishment that would trigger constitutional scrutiny. ${ }^{82}$

This rationale was extended during the Cold War to the indefinite detention of those whom the government wished to deport, but had nowhere to go. ${ }^{83}$ The plenary power doctrine continues to be the standard applied. ${ }^{84}$ In clear violation of international human rights and refugee law, this plenary power rationale has been used to allow the indefinite detention of Mariel Cubans, ${ }^{85}$ the interception and forced return of fleeing Haitians found on the high seas, ${ }^{86}$ and the refusal to allow undocumented Chinese laborers and

80 Chae Chan Ping v. United States, 130 U.S. 581, 600 (1889) ("the last expression of the sovereign will must control")

81 Id. at 606.

82 Fong Yue Ting v. United States, 149 U.S. 698, 730-34 (1893).

83 See Shaughnessy v. United States ex rel. Mezei, 345 U.S. 206, 208 (1953) (allowing a returning permanent resident to be held indefinitely on Ellis Island, without a hearing, on the Attorney General's assertion that his entry would be "prejudicial to the public interest").

84 See generally Stephen H. Legomsky, Immigration Law and the Principle of Plenary Congressional Power, 1984 SUP. CT. REV. 255; Hiroshi Motomura, Immigration Law After a Century of Plenary Power: Phantom Constitutional Norms and Statutory Interpretation, 100 YALE L.J. 545 (1990); ALEINIKOFF, SEMBLANCES OF SOVEREIGNTY, supra note 26.

85 See Fernandez-Roque v. Smith, 734 F.2d 576 (11th Cir. 1984); Garcia-Mir v. Meese, 788 F.2d 1446 (11th Cir. 1986); Richard A. Boswell, Throwing Away the Key: Limits on the Plenary Power?, 18 MiCH. J. INT'L L. 689, 702 (1997) (book review) (noting that Cuban prisoners were not accorded Eighth Amendment rights even while held in maximum security federal prisons because immigration detention was deemed civil, not criminal); see generally Margaret H. Taylor, Detained Aliens Challenging Conditions of Confinement and the Porous Border of the Plenary Power Doctrine, 22 HASTINGS Const. L.Q. 1087 (1995)

86 See Sale v. Haitian Centers Council, Inc., 509 U.S. 155 (1993) (holding that neither the Refugee Convention nor U.S. immigration statutes would be applied to actions on the high seas); see generally Bill Frelick, Haitian Boat Interdiction and Return: First Asylum and First Principles of Refugee Protection, 26 CORNELL INT'L L.J. 675 (1993). 
asylum seekers to land in U.S. ports. ${ }^{87}$ In 1984 the Eleventh Circuit, relying on these cases, held in Jean v. Nelson that Haitian refugees seeking political asylum could be incarcerated because noncitizens who have not been admitted continue to "have no constitutional rights with regard to their applications, and must be content to accept whatever statutory rights and privileges they are granted by Congress., ${ }^{88}$ The following year the Supreme Court refused to grant certiorari in Garcia-Mir v. Meese, which followed Jean, noting specifically that claims under international human rights law were inapplicable to the plight of indefinitely detained Mariel Cubans. ${ }^{89}$

In sum, the plenary power doctrine under which the Supreme Court has refused to apply constitutional constraints to the actions of the "political" branches has been applied in immigration law, what is termed "federal Indian law," and the governance of peoples living in territories occupied by but not incorporated into the United States. All told, this means that tens of millions of people-both citizens and noncitizens - are subjected to the political and military jurisdiction of the United States with no guarantee that their basic human rights will be protected except to the extent that the United States recognizes and enforces international law. The Constitution is not providing "better" protection to them, because in many aspects of their lives it is not even considered applicable.

\section{Military Necessity_Plenary Power Meets the War on Terror}

In cases in which the government has asserted "military necessity," the Supreme Court has been almost as deferential as it has been in the plenary power cases. Thus, for example, in upholding the internment of nearly 120,000 Japanese Americans, two-thirds of them U.S. citizens, during World War II, ${ }^{90}$ the Court purported to engage in a constitutional analysis, and even announced the "strict scrutiny" standard for race-based classifica-

87 See Department of Transportation, U.S. Coast Guard, Statement of Anthony Tangeman to the Subcommittee on Migration and Claims Committee on the Judiciary, U.S. House of Representatives (May 18, 1999), available at 1999 WL 16947941 (noting that between 1991 and 1999 the Coast Guard had intercepted over 5,000 Chinese migrants).

88 Jean v. Nelson, 727 F.2d 957, 968 (11th Cir. 1984). The Supreme Court subsequently held that the Eleventh Circuit should not have reached the constitutional question and declined to revisit the Cold War plenary power cases. Jean v. Nelson, 472 U.S. 846, 854-55 (1985).

89788 F.2d 1453-55 (11th Cir. 1986), cert. denied, 479 U.S. 889 (1986).

90 See Hirabayashi v. United States, 320 U.S. 81 (1943) (upholding conviction for curfew violation but failing to reach the merits on conviction for violating evacuation order); Yasui v. United States, 320 U.S. 115 (1943) (upholding conviction for curfew violation); Korematsu v. United States, 323 U.S. 214 (1944) (upholding the evacuation as constitutional but not reaching the internment itself); and $E x$ parte Endo, 323 U.S. 283 (1944) (holding that a citizen acknowledged by the government to be "loyal" could not continue to be interned). See generally Eugene V. Rostow, The Japanese American Cases: A Disaster, 54 YALE L.J. 489 (1945) (criticizing the Court's abdication of its constitutional responsibilities); Jerry Kang, Watching the Watchers: Enemy Combatants in the Internment's Shadows, 68 J. L. \& CONTEMP. PROBS. 255 (2005) (criticizing judicial deference in inter alia the Endo decision). 
tions. ${ }^{91}$ Nonetheless, as summarized in 1945 by Yale Law Professor Eugene Rostow, the majority of the justices in each case simply parroted the government's assertions that "the Japanese [were] a dangerous lot, and that there was no time to screen them individually." pointed out, that the Court made "no attempt [to require the government] to show a reasonable connection between the factual situation and the program adopted to deal with it." ${ }^{, 33}$ While the Japanese American internment is widely acknowledged to have been a gross violation of fundamental human rights, its sanctioning by the Supreme Court still stands as "good" precedent. $^{94}$

Recent actions by the U.S. government in its "war on terror" illustrate that the judiciary is imposing virtually no restraints on violations of international law, including both humanitarian and human rights law, on large scales or small. One aspect of what we have seen has been a straightforward refusal to acknowledge the applicability of well-established tenets of international law to U.S. actions. Thus, we have U.S. government officials claiming falsely that the Geneva Conventions do not apply to the war in Afghanistan, to certain detainees in Iraq, or to those held at the U.S. naval base in Guantánamo Bay, Cuba, ${ }^{95}$ and attempting to exempt themselves generally from customary law, and even jus cogens norms, such as the prohibition on torture. ${ }^{96}$

More than six hundred men and boys from over forty countries, some as young as thirteen, most apparently captured in Afghanistan, have been held and interrogated at the U.S. naval base in Guantánamo. In direct violation of the Geneva Conventions, the U.S. has maintained, without providing evidence, that they are "unlawful combatants" and need not be accorded the rights of prisoners of war. ${ }^{97}$ U.S. officials have engaged in, and officially sanctioned, a variety of "interrogation" techniques that clearly violate inter-

91 Korematsu v. United States, 323 U.S. at 216.

92 Rostow, supra note 90 , at 508.

93 Id. 508-09.

94 The convictions of Hirabayashi and Korematsu were subsequently overturned by lower courts on writs of error coram nobis but these decisions, of course, do not change Supreme Court precedent. See Korematsu v. United States, 584 F. Supp. 1406 (N.D. Cal. 1984); Hirabayashi v. United States, 828 F.2d 591 (9th Cir. 1987).

95 See Paust, Executive Plans, supra note 8 at $824-851$.

96 Id. at 856 (quoting memo from Justice Dept. attorneys Yoo and Delahunty baldly stating "that customary international law, whatever its source and content, does not bind the President, or restrict the actions of United States military, because it does not constitute federal law.") On attempts to legitimize torture, see id. at $838-850$.

97 See id. at 841-42 (noting Defense Secretary Rumsfeld's May 2004 statement to a Senate committee that the Geneva Conventions do not apply to prisoners at Guantánamo Bay because they are "terrorists"); see also Katharine Q. Seelye, Detainees Are Not P.O.W.s Cheney and Rumsfeld Declare, N.Y. TimeS, Jan. 28, 2002, at A6. See generally Jonathan Canfield, Note, The Torture Memos: The Conflict Between a Shift in U.S. Policy Towards a Condemnation of Human Rights and International Prohibitions Against the Use of Torture, 33 HofSTRA L. REV. 1049 (2005). 
national prohibitions on torture. ${ }^{98}$ Again undermining the argument that international norms can be disregarded because the Constitution provides adequate protection, constitutional protections are being denied the detainees because, even though they are clearly under U.S. jurisdiction, the Guantánamo naval base is "outside" the United States. In June 2004 the Supreme Court did hold that the detainees have a right to have their status determined by a "neutral decisionmaker," but fell far short of extending them the full range of constitutional protections.

"Extraordinary rendition," or the sending of prisoners to other countries, presumably for interrogation, has been another way of avoiding compliance with both international and constitutional prohibitions on torture. The first civil case challenging this practice is now in court, brought by a naturalized Canadian citizen, Maher Arar, who was detained while changing planes in New York, held in solitary confinement in a Brooklyn jail, then sent to Syria and interrogated under torture. While one would think that basic constitutional protections would apply to all persons while held in custody within the U.S., government lawyers argued that detaining foreign citizens who are merely changing planes in the U.S., holding them without charge or access to counsel, and even denying them basic necessities such as food is legal.

The government's argument, based solidly in immigration cases where the Court has deferred to the "plenary power" of Congress and the Executive, is that under immigration law, anyone presenting a foreign passport, even if only changing planes, can be considered to be "seeking admission" into the U.S., and that anyone deemed "inadmissible," even wrongly or illegally, remains "outside" the U.S. and therefore outside the protections of the Constitution. ${ }^{100}$ Clearly, if the Constitution were to be interpreted in accordance with applicable human rights law, the resort to such legal fictions would not occur.

In the meantime, at least two U.S. citizens have been detained for several years in U.S. military prisons, without charge and, for a long period, without access to lawyers, on the government's assertion that they are "enemy combatants." Faced with a Supreme Court ruling that Yaser Hamdi

98 See Paust, Executive Plans, supra note 8 at 838-46. See also Natsu Taylor Saito, Will Force Trump Legality After September 11? American Jurisprudence Confronts the Rule of Law, 17 GeO. IMMIG. L.J. 1, 10-12, 14-31 (outlining violations of both the Constitution and applicable international law).

99 See Rasul v. Bush, 542 U.S. 466 (2004); see generally Jordan J. Paust, After 9/11, "No Neutral Ground" With Respect to Human Rights: Executive Claims and Actions of Special Concern and International Law Regarding the Disappearance of Detainees, 50 WAYNE L. REV. 79 (2004) (discussing both the Guantánamo detainees and "special interest" immigrant detainees).

100 See Nina Bernstein, U.S. Defends Detentions At Airports, N.Y. TimEs, Aug. 10, 2005 at A16; see generally Joan Fitzpatrick, Rendition and Transfer in the War Against Terrorism: Guantánamo and Beyond, 25 LOY. L.A. INT'L \& COMP. L. REV. 457 (2003). 
was entitled to a hearing to contest this designation, the government chose instead to deport him to Saudi Arabia, releasing him in return for his relinquishment of U.S. citizenship. ${ }^{101}$ Jose Padilla, continues to be held, pending the refiling of his federal lawsuit. ${ }^{102}$ Padilla is a U.S. citizen, born in Brooklyn, arrested at Chicago's O'Hare Airport and suspected, apparently, of involvement in a plan to use a "dirty bomb." ${ }^{\text {"103 }}$ Nothing in this scenario explains why he should not be prosecuted under applicable criminal laws, with attendant constitutional protections. Again, constitutional protections appear to have evaporated, leaving Padilla with nothing comparable to the protections he should have under international law.

These are but a few of many examples illustrating the failure of the U.S. government to comply with the most basic requirements of international human rights and humanitarian law, and the reluctance of the Supreme Court to enforce such rights, either under the Constitution or international law. Coming as they do from many different areas of law, affecting a wide range of citizens and noncitizens, and occurring consistently over time, they illustrate that such instances cannot be dismissed as mere aberrations, or occasional mistakes, or responses to a national emergency. Instead, they force us, I believe, to acknowledge that U.S. constitutionalism as it has been implemented fails to protect the most basic human rights.

\section{The Potential for U.S. Constitutionalism}

In the 1990s we witnessed the emergence of a small number of rogue states.... These states:

Brutalize their own people and squander their national resources for the personal gain of the rulers.

Display no regard for international law, threaten their neighbors, and callously violate international treaties to which they are a party.

Are determined to acquire weapons of mass destruction, along with other advanced military technology, to be used as threats or offensively to achieve the aggressive designs of these regimes.

101 See Hamdi v. Rumsfeld, 542 U.S. 507 (2004); see generally Charles I. Lugosi, Rule of Law or Rule By Law: The Detention of Yasir Hamdi, 30 AM. J. CRIM. L. 225 (2003).

102 See Rumsfeld v. Padilla, 542 U.S. 426 (2004).

103 See Laurence H. Tribe, Citizens, Combatants and the Constitution, N.Y. TimeS, June 16, 2002, at A13 ("Secretary of Defense Donald Rumsfeld's assertion that the United States is holding Mr. Padilla because it is 'interested in finding out what he knows' is not legally persuasive."); see also Military Tribunal Won't Try Padilla, Justice Dept. Says, WASH. Post, June 14 2002, at A10 (reporting Justice Dept. claim that the United States can hold Padilla until the war against terrorism is over); Chris K. Iijima, Shooting Justice Jackson's "Loaded Weapon" at Ysar Hamdi: Judicial Abdication at the Convergence of Korematsu and McCarthy, 54 SYRACUSE L. REV. 109, 134-38 (2004) (discussing the government's refusal to divulge any evidentiary basis for holding Padilla). 
Sponsor terrorism around the globe.

Reject basic human values and hate the United States and everything for which it stands.

George W. Bush, Introduction to The National Security Strategy of the United States ${ }^{104}$

The fact that the Supreme Court has construed the first eight amendments to the Constitution in an increasingly restrictive fashion and virtually ignored the ninth does not diminish the impact that international human right law could, and should, have within the framework of U.S. constitutionalism. Even within the cramped confines of the "last in time" rule, the Court has stated that domestic legislation should be interpreted, where possible, to conform to U.S. treaty obligations. ${ }^{105}$ Applying this principle a bit more broadly, if the judiciary were to take the incorporation of international law into U.S. law seriously, it would be a fairly simple matter legally, if not politically, to interpret constitutional rights as at least coextensive with, if not more protective than, international human rights law and, more generally, to integrate international and domestic law.

If we were to return to first principles, acknowledging the importance of U.S. compliance with international law, both because it is a necessary component of functioning as a legitimate state and because the framers understood and incorporated this principle into the Constitution, virtually all perceived contradictions between domestic law and international human rights could be eliminated and U.S. constitutionalism strengthened. This would require the Supreme Court to take seriously its acknowledged responsibility to treat the "law of nations" as an integral part of the supreme law of the land, as well as its mandate under Article III to ensure that both executive action and congressional legislation comport with the Constitution, without exception. Such judicial intervention would not be necessary, of course, if the "political" branches adhered to their mandate to enact and execute legislation and policy which conforms to both the Constitution and international law.

Acknowledgment that international law is an integral part of U.S. law would remove domestic incentives for failing to ratify or fully participate in international conventions and institutions, eliminate much international criticism about the United States for its apparent hypocrisy and, in the process, do away with much of the foreign policy-based motivations for attacks on the United States and its nationals. In turn, this would put the U.S. in the

104 National Security Report, supra note 1.

105 See Whitney v. Robertson, 124 U.S. 190, 194 (1888) ("the courts will always endeavor to construe them so as to give effect to both, if that can be done without violating the language of either"). 
position of actually being able to strengthen the international human rights regime, both with respect to the articulation of law and its effective enforcement.

While this would require a fundamental reorientation of perspective, the potential for such change is what makes the Constitution a viable foundation for a truly democratic society. We have weathered major shifts in our understanding of Constitutional reach before, and can do it again. While the executive has increasingly distanced itself from international law and institutions, at least with respect to humanitarian and human rights law-the same certainly cannot be said for international structures of economic order ${ }^{106}$ - the judiciary has made tentative moves in the opposite direction.

Since the Second Circuit's 1980 decision in Filártiga v. Peña-Irala, federal courts have allowed civil suits based on egregious violations of customary international law to be brought under the Alien Tort Claims Act (ATCA). ${ }^{107}$ As recently as 2004, the Court acknowledged jurisdiction over claims involving violations of a norm of "international character accepted by the civilized world." ${ }^{108}$ As Yale Law School Dean Harold Koh has noted, that "[i]n Filartiga, transnational public law litigants finally found their Brown v. Board of Education." 109 The ability of foreign nationals to bring suits under ATCA led Congress to pass the Torture Victim Protection Act, making it easier for U.S. citizens to enforce at least some of these customary rights in U.S. courts. ${ }^{110}$

One criticism of this line of cases has been that they have focused on abuses committed outside the United States, reinforcing the notion that human rights law needs to be enforced "out there." However, there has been an encouraging recognition of international norms, if not their explicit enforcement, in recent Supreme Court cases dealing exclusively with domes-

106 On the disparate treatment of human rights and trade-related treaties, see generally Connie de la Vega, Human Rights and Trade: Inconsistent Application of Treaty Law in the United States, 9 UCLA J. INT'L L. \& FOR. AFFAIRS 1 (2004).

107 Filártiga v. Peña-Irala, 630 F.2d 876 (2d Cir. 1980); see also Human Rights Litigation Hilao v. Estate of Ferdinand Marcos, 25 F.3d 1467 (9th Cir. 1994); Xuncax v. Gramajo, 886 F. Supp. 162 (D.Mass. 1995); Forti v. Suarez-Mason, 694 F. Supp. 707 (1988); Abebe-Jira v. Negewo, 72 F.3d 844 (11th Cir. 1996). The ATCA, also known as the Alien Tort Statute, is found at 28 U.S.C. $\$ 1350$ (1948) On executive efforts to curtail this trend, see generally Beth Stephens, Upsetting Checks and Balances: The Bush Administration's Efforts to Limit Human Rights Litigation, 17 HARV. HUM. RTS. J. 169 (2004).

108 Sosa v. Alvarez-Machain, 542 U.S. 692, 124 S. Ct. 2739, 2761 (2004).

109 Harold Hongju Koh, Transnational Public Law Litigation, 100 YaLE L.J. 2347, 2366 (19901991); see generally Beth Van Schaack, With All Deliberate Speed: Civil Human Rights Litigation as a Tool for Social Change, 57 VAND. L. REV. 2305 (2004).

110106 Stat. 73 (1992), codified as 28 U.S.C. $\$ 1350$ (2000); see generally Eric Engle, The Torture Victim's Protection Act and the Alien Tort Claims Act, and Foucault's Archaeology of Knowledge, 67 ALB. L. REV. 501 (2003); Ryan Goodman, Congressional Support for Customary International Human Rights as Federal Common Law: Lessons of the Torture Victim Protection Act, 4 ILSA J. INT'L \& CoMP. L. 455 (1998). 
tic concerns. Thus, in holding the execution of mentally retarded persons unconstitutional in 2002, Justice Stevens, writing for the majority, explained that "within the world community, the imposition of the death penalty for crimes committed by mentally retarded offenders is overwhelmingly disapproved." Similarly, in the Supreme Court held in 2005 that the execution of persons for crimes committed while under the age of eighteen violated the Eight and Fourteenth Amendments. ${ }^{112}$ The majority noted that the "overwhelming weight of international opinion against the juvenile death penalty is not controlling here, but provides respected and significant confirmation" of its decision. ${ }^{13}$ In recent university admissions affirmative action cases, Justice Ginsburg, joined in one instance by Justice Breyer and in another by Justice Souter, referenced the ICERD and "[c]ontemporary human rights documents." " Striking down Texas sodomy laws, Justice Kennedy's majority opinion cited to holdings of the European Court of Human Rights, noting that the right sought "has been accepted as an integral part of human freedom in many other countries." 115 State courts-as well as legislatures - have the ability to directly invoke international law ${ }^{116}$ and San Francisco recently addressed public sector discrimination by passing an ordinance based upon the Convention on the Elimination of Discrimination Against Women. ${ }^{117}$

If these tendencies were expanded and international norms fully incorporated into U.S. judicial decisions and governmental action, many of the harms referenced above - the denial of basic rights under the rubric of plenary power, the disappearances and arbitrary detentions of immigrants, the torture and abuse of detainees, and other violations of the laws of war and fundamental human rights - could be avoided. As currently interpreted and implemented, however, U.S. constitutionalism is a very dangerous proposition. As many have noted, the hypocrisy embodied in American exceptionalism generates anger and frustration around the world, fueling the very

111 See Atkins v. Virginia, 536 U.S. 304 (2002). See generally Bronstein \& Gainsborough, supra note 61; Linda A. Malone, From Breard to Atkins to Malvo: Legal Incompetency and Human Rights Norms on the Fringes of the Death Penalty, 13 WM. \& MARY BiLL RTS. J. 363 (2004).

112 See Roper v. Simmons, 125 S. Ct. 1183 (Mar. 1, 2005), overruling Stanford v. Kentucky, 492 U.S. 361 (1989); see also State ex rel. Simmons v. Roper, 112 S.W.3d 397, 400-411 (Mo. 2003) (finding execution for a crime committed by a juvenile prohibited by the Missouri Constitution, with reference to applicable international norms, including the Convention on the Rights of the Child).

$113125 \mathrm{~S}$. Ct. at 1186.

114 Grutter v. Bollinger, 539 U.S. 306, 344 (2003) (Ginsburg, J. concurring); Gratz v. Bollinger, 539 U.S. 244, 302 (2003) (Ginsburg, J., concurring).

115 Lawrence v. Texas, 539 U.S. 558, 577 (2003).

116 See generally Penny J. White, Legal, Political, and Ethical Hurdles to Applying International Human Rights Law in the State Courts of the United States (and Arguments for Scaling Them), 71 U. CINN. L. REV. 937 (2003).

117 See generally Stacy Laira Lozner, Diffusion of Local Regulatory Innovations: The San Francisco CEDAW Ordinance and the New York City Human Rights Initiative, 104 COL. L. REV. 768 (2004). 
forces which are used by the United States as a justification for further violations of international law, and giving other governments ground for similar cutbacks in human rights protections. ${ }^{118}$ Employed in this manner, U.S. constitutionalism is caught in a downward spiral eviscerating the human rights regime constructed so painfully over the past six decades.

There is, however, nothing necessary or inevitable about this process. The most fundamental principles of U.S. constitutionalism allow, even mandate, the incorporation of international law, and the Constitution could, with relative ease, be interpreted to encompass protections at least as extensive as those articulated in human rights law. In the current climate it is, notably, the executive and legislative branches of government-those designed to be most accountable to the citizenry-which have moved most decisively to constrict human rights. But this should also give us hope, for if this is in fact a democracy, we have the ability to reverse that trend.

This is the choice we face. In The Dual State, written in 1940, Ernst Fraenkel described the transition in the German government from a normative state, "endowed with elaborate powers for safeguarding the legal order" to a prerogative state, defined as a "governmental system which exercises unlimited arbitrariness and violence unchecked by any legal guarantees." "We can sit back and watch a similar transition, allowing the United States to function as a rogue state meeting all of the criteria enumerated above by President Bush - aside, perhaps, from the self-insulating assertion that such a state, by definition, "hate[s] the United States and everything for which it stands." We can allow constitutional protections to be treated as optional and international law to become Senator Jesse Helms' "dead cat on the doorstep," trusting, as Justice Brown said in Downes v. Bidwell, that we need not worry about despotism for "there are certain principles of natural justice inherent in the Anglo-Saxon character which need no expression in constitutions or statutes." 120 Or we can seize the opportunity to strengthen and revitalize U.S. constitutionalism by returning to the founders' vision of a legal order directly incorporating international law and its evolving protection of fundamental human rights.

\footnotetext{
118 See Anthea Roberts, Righting Wrongs or Wronging Rights? The United States and Human Rights Post-September 11, 15 EUR. J. INT'L L. 721, 731-35 (2004) (discussing the "world's responses").

119 ERnst Fraenkel, The Dual State: A Contribution to the TheOry of Dictatorship xiii (1969 reprint of 1941 original); see also Michael Stolleis, The Law Under the Swastika: Studies on Legal History in Nazi Germany 8, 193 n.3 (1998) (noting that the transition from a normative to a prerogative state was accomplished by gradual changes in the law).

120182 U.S. 244, 280 (1901). This was, of course, the same Justice Brown who, just five years earlier, had written the Court's opinion upholding legalized apartheid in Plessy v. Ferguson, 163 U.S. 537 (1896).
} 